\title{
Social Insurance for Informal Workers in Magelang- Indonesia: Why Is Participation Still Low?
}

\author{
Retno Rusdjijati ${ }^{1}$, Agus Widodo ${ }^{2}$, Jack Roebijoso ${ }^{3}$, Harsuko Riniwati ${ }^{4}$ \\ \{E-mail: rusdjijati@ummgl.ac.id\} \\ ${ }^{1}$ Student of the Environmental Sciences Doctoral Program, Universitas Brawijaya Malang, Indonesia \\ ${ }^{2}$ Department of Mathematics, FMIPA, Universitas Brawijaya Malang, Indonesia \\ ${ }^{3}$ Faculty of Medicine, Universitas Brawijaya Malang, Indonesia \\ ${ }^{4}$ Fisheries Agribusiness Department, Faculty of Fisheries and Marine Science, Universitas Brawijaya \\ Malang, Indonesia
}

\begin{abstract}
Although the Government of Indonesia has issued the regulation on Social Security Implementing Agency (BPJS) since 2004, the participation of informal workers to access insurance is still low, including in the six industries that produce featured products in Magelang Regency. Therefore, this study was conducted by survey and indepth interviews with a group of respondents to find the influencing variables by a fishbone diagram analysis. As a result, the causes of low BPJS participation are influenced by low levels of education, age factors, low knowledge, low incomes, high necessities of life, and also the lack of BPJS socialization to them. These problems can be grouped into manageable and non-manageable variables, which require a balanced solution to increase participation in BPJS.
\end{abstract}

Keyword : Government, Education, BPJS.

\section{Introduction}

Informal workers are workers in the business sector of the informal economy or workers who carry out work out-of-work-relation, who carry out economic activities without others' assistance (selfemployed without labour/workers). These workers, on the concept of social security organized by Social Security Implementing Agency (BPJS), are referred to as NonWage Recipients. In general, they do business in the informal economy with characteristics such as microscale with small capital, using simple, low technology, producing goods and or services with relatively low quality, irregular business places, very high worker mobility, not guaranteed business continuity, uncertain working hours, productivity and income levels are relatively small and insecure.

Informal workers are groups of workers who are existing but not intangible, so they are often mistreated. They have volatile income; often ignoring applicable laws, regulations and taxes, not protected by labor laws; most do not receive minimum wages; always be in uncertain conditions such as product marketing, production processes, and work plans; unable to access social security such as cases of death, disability, sickness, maternity, old age and unemployment; less able to develop skills, access revolving funds, and obtain appropriate health services; no organization, no agent, and no bargaining power. Also, they do not understand their rights as workers; and have health problems and unsafe working conditions 
due to lack of knowledge and understanding of occupational health and safety, including the risk of hazardous work environments [1].

Informal workers also have the same rights as formal workers, especially in obtaining protection as stated in article 3 paragraph 2 of Law Number 32 of 1992 concerning Labor Social Security that every workforce has the right to social security of workers. These informal workers have the right to be protected from work risks, such as death, accident, illness, and compensation in entering old age. However, Law No. 32 of 1992 has not been able to provide optimal social protection to informal workers. After the enactment of Law No. 40 of 2004 concerning the Social Security System, social protection for casual workers began to be implemented. The implementation of Law Number 40 of 2004 was also ineffective so that the application of Social Security continued to develop on its own, without feeling that there was someone who "overshadowed" [2].

The causes include socialization that is not optimal causing the concept of Social Insurance to be less well known to the public and supporting legal instruments that are still minimal. Informal workers are categorized as labour outside the employment relationship, so they become voluntary participants with a maximum age limit of 55 years. The legal basis for this type of worker program refers to Ministerial Regulation Number 24/MEN/IV/2006 concerning Guidelines for Implementing the Social Security Program for Workers Outside Employment Relations. As a result, informal workers are less touched, so that social protection for them cannot be optimized. Furthermore, Law No. 24/2011 concerning the National Social Security System is then stipulated. The formal legal source for the formation of this Law is Law Number 24 of 2004, which explains that the Social Security Organizing Body must be established with a Law which is the transformation of the four State-Owned Enterprises namely Social Security, Taspen, Asabri, and Askes (Article 5 paragraph 1 and article 52). The purpose of establishing Law No. 24 of 2011 is to accelerate the implementation of a national social security system for all Indonesian people.

However, this new law also seems to be unable to optimize social protection for informal workers. The insurance participation of the informal sector is still low, due to ignorance of the existence of employment social security programs; little awareness of the informal sector on the benefits of insurance; inability to pay monthly insurance dues; inadequate human resources of BPJS employment officers as well as facilities and infrastructure [3]. The BPJS Law is not by the mandate of the 1945 Constitution. Article 28H paragraph (3) of the 1945 Constitution states that everyone has the right to social security, while in the BPJS law article 1 paragraph (8) explains that workers are everyone who works by receiving salaries, wages, or other forms of compensation. This definition is in contrast with the conditions of informal workers because they are workers who are self-employed and are out-ofwork-relation, so they do not receive wages or other forms of compensation. The BPJS law is also not by law number 3 of 1992 concerning workers' social security related to social protection for informal workers. MSME doers consisting of workers, employers, and independent workers have minimal knowledge about the National Social Security System (SJSN) [4]. Nevertheless, they have a high enthusiasm for joining the SJSN program, with the priority of health insurance programs and work accident insurance. The ability and willingness to become a BPJS participant are significantly influenced by income level, education level, and level of knowledge about the BPJS program.

Kansra \& Gill [5] states that health insurance has been held in India, but only 48.3 per cent of informal sector workers are aware of the importance of health insurance and even then not all of them are active insurance participants. Furthermore, in Thailand according to the results of a 2012 survey, the number of informal sector workers was $24,800,000$ or 62.6 per cent of 
the total workers. The casual sector workers also have no work insurance, protection, and social welfare [1]. If they are sick, they prefer public hospitals for treatment; 59.2 per cent are not willing to become insurance participants; those who have insurance, generally choose the lowest price of less than 5,000 Baht/year; the most popular is silver health insurance with care; health insurance selected by informal sector workers generally who provide care service of joint disease, accident, and surgery; the most popular are annual payments (28 per cent); most informal workers choose to buy health insurance along with life insurance (48 per cent); and hospitalizations and outpatients were the most selected ( 32 per cent) in public hospitals ( 27 per cent).

Magelang District is one of the regions in Central Java Province. The population reached 1,272,624 people or around 3.76 per cent of the community of Central Java Province in 2016. Most of the residents are informal workers, amounting to 449,138 people or 63.7 percent of the total workforce. The number of workers in small industries, which is one type of casual worker, until 2016 reached 71,657 people. These workers are spread in 21 sub-districts both individually and in the form of industrial centers. The products produced include food, various handicrafts, and services. The 2016 Department of Industry and Manpower Study stated that there were six featured products in Magelang District, namely processed salak in Kaliurang Srumbung, stone chisel in Sedayu Muntilan, rayung broom in Bojong Mungkid, coconut sugar in Kebonrejo Candimulyo, processed coffee in Branch and slondok in Sumurarum Grabag.

The results of preliminary research on 23 workers from 4 industrial centres state that only two people are participants of the Employment-BPJS and four people who are participants of the HealthBPJS, while only one person is a participant in the BPJS Employment and Health BPJS. In fact, based on the results of identification of potential danger using the Job Safety Analysis and Risk Assessment method, the broom industry has a risk of uncertainty that can still be tolerated; processed coffee industries and slondok industries have a chance of danger that must be controlled to the tolerance limit; and the processed salak industry has a risk of danger that must be monitored intensively and controlled. The next study will analyze the root causes of low employee's participation in the BPJS, and find solutions to increase the engagement.

\section{Method}

This research was conducted with a qualitative descriptive method. To find the root of the problem, the focus group discussion was carried out with the help of a fishbone diagram. Question "5 Why" in the fishbone diagram is asked to look for problems and solutions. The design of the study used cross-sectional studies that aim to collect information over some time simultaneously. The study was conducted from 23 September 2018-23 October 2018 in 6 centres of featured product industries in Magelang District, namely in Ngrancah Village and Sumurarum Village, Grabag Subdistrict, Kebonrejo Village, Candimulyo Subdistrict, Bojong Village, Mungkid District, Sedayu Village, Muntilan District, and Kaliurang Village, Srumbung Village. The samples were 172 people. It used the snowball sampling technique.

Fishbone diagram can help and enable every person, organization or company to solve problems by identifying the root causes of issues and making efforts to deal with the root causes of problems. The identification of objects is limited to only six factors, namely man, method, money, market, information and time. If the leading causes have been identified, it is followed by identifying as many factors as possible from each of the leading causes, then the 
principle of 'why', which aims to continue to question how one can happen, is applied with the brainstorming process carried out jointly and in accordance with the facts in the field or information that has been collected. This aims to identify the more detail causes of the problem so that it is placed on a smaller size fishbone. Furthermore, reviewing and agreeing on potential causes, which is possibly become the root cause of the problem. The possible reason is characterized by potential causes that repeatedly appear or appear in more than one category so that they can be considered as the root cause of the problem.

\section{Result and Discussion}

\subsection{Respondent Profile}

The 172 respondents were all men with a high school education level of 44 per cent and the rest never went to school (4 per cent), went to elementary school (23.25 per cent), and went to junior high school (28.75 per cent). Generally, they conduct business activities with their capital (78 per cent) and loans ( 22 per cent), so that the business capital is limited, even though as many as 87.7 per cent of respondents stated that their business prospects were good.

\subsection{Employment-BPJS Participation}

Based on the filled questionnaire, the respondents who were the participants of the Employment BPJS were only 10.57 per cent, while others stated that they surrender (44.4 per cent) if there was a risk from their work, and as many as 45.03 per cent chose to save to face the possible risks occurred. The reason they did not be participants of the Employment BPJS was the low income (29.6 per cent); limited capital (24.4 per cent); BPJS was considered not necessary (5.81 per cent), and the rest did not provide answers. However, the respondents still stated that being an Employment-BPJS participant was necessary (85.96 per cent), although as many as $50.87 \%$ did not know that becoming an EmploymentBPJS participant was the right of every citizen. Thus the respondents were willing to become participants of the EmploymentBPJS (77.77 per cent) with the condition that socialization is conducted (31.9 per cent) so that knowledge of Employment-BPJS increases; funds from participants are well managed (19 per cent); secure submission procedures (20.9 per cent) ); affordable fees (41.7 per cent). According to the results of the interview, especially with the rayung broom makers who stated that there was no participation of Employment-BPJS because they considered the danger of the risk arising from the work environment was relatively small, so that to work accidents or work-related illnesses were not possible. There were also those who stated that they were antiBPJS because they saw their friends' experiences that did not recover with health services through BPJS.

On the side of the management of the Employment-BPJS itself, the informal sector workers were challenging to touch because the data was unclear so that it was difficult for BPJS to contact. Besides, human resources from BPJS were also limited. However, BPJS had not made much effort to collaborate with other parties such as Employment Agency or the Department of Industry and MSMEs, or with universities that often assist informal sector workers. 


\subsection{Knowledge on BPJS}

The respondents who knew what BPJS stands for were 78.2 per cent; who knew what BPJS goals were 78.2 per cent; who knew the criteria for PBI participants were 16.2 per cent; who knew the requirements for participants, not PBI / independent were 19 per cent; who knew the first health services referred were 61.97 per cent, secondly health services related were 85.9 per cent; who knew the health services serve BPJS was 100 per cent; who knew health services limited by BPJS were 19 per cent; who know health services guaranteed by BPJS were 74.6 per cent; and who knew the use-time of BPJS was 86.6 per cent. The average level of knowledge of respondents about BPJS was 61.97 per cent.

\subsection{Discussion}

The results of the questionnaire indicate that the causes of low participation of informal workers in BPJS Employment are 1) low education level, 2) average age above 40 years, 3) limited business capital, 4) not knowing that BPJS is the right of every citizen, 5 ) low income, 6) expensive dues, 7) BPJS is considered unimportant, 8) lack of socialization, 9) distrust that paid dues are well managed, and 10) procedure for submission is steep.

The results of the questionnaire were then grouped into six factors, namely man, method, money, market, information, and time $(4 \mathrm{M}+1 \mathrm{I}+1 \mathrm{~T})$. The causal factors that had been identified were then used as a basis in preparing a fishbone diagram. If the causes of the problem had been categorized based on $4 \mathrm{M}+1 \mathrm{I}+1 \mathrm{~T}$, then a study was conducted to determine the possible reasons that were the root cause of the problem, as presented in Table 1.

Table 1. Analysis result of the root of problem causes

\begin{tabular}{|c|c|c|c|}
\hline Factors & Cause 1 & Cause 2 & Cause 3 \\
\hline \multirow[t]{5}{*}{ Man (M1) } & $\begin{array}{l}\text { The respondents did not } \\
\text { understand about } \\
\text { BPJS (M1.1) }\end{array}$ & $\begin{array}{l}\text { Low knowledge on BPJS } \\
\text { (M1.1.1) }\end{array}$ & $\begin{array}{l}\text { Respondents were }> \\
40 \text { years old } \\
\text { (M1.1.1.1) }\end{array}$ \\
\hline & & & $\begin{array}{l}\text { Low education level } \\
\text { (M1.1.1.2) }\end{array}$ \\
\hline & & $\begin{array}{l}\text { Respondents tend to } \\
\text { surrender (M1.2.1) }\end{array}$ & \\
\hline & & $\begin{array}{l}\text { Respondents save for } \\
\text { preparation in case of } \\
\text { a case (M1.2.2) }\end{array}$ & \\
\hline & $\begin{array}{l}\text { Respondents have not } \\
\text { considered } \\
\text { important (M1.2) }\end{array}$ & $\begin{array}{l}\text { Respondents consider } \\
\text { the risk of danger from } \\
\text { work } \\
\text { environment small } \\
\text { (M1.2.3) }\end{array}$ & \\
\hline Method (M2) & $\begin{array}{l}\text { The procedure for } \\
\text { participants registration } \\
\text { is } \\
\text { difficult to access (M2.1) }\end{array}$ & $\begin{array}{l}\text { Lack of socialization } \\
\text { (M2.1.1) }\end{array}$ & $\begin{array}{l}\text { Low respondents' } \\
\text { knowledge } \\
(\mathrm{M} 2.1 .1 .1)\end{array}$ \\
\hline Money (M3) & $\begin{array}{l}\text { Limited business capital } \\
\text { (M3.1) }\end{array}$ & $\begin{array}{l}\text { Self Business Capital } \\
\text { (M3.1.1) }\end{array}$ & $\begin{array}{l}\text { Low income } \\
\text { (M3.1.1.1) }\end{array}$ \\
\hline
\end{tabular}




\begin{tabular}{|c|c|c|c|}
\hline Factors & Cause 1 & $\begin{array}{c}\text { Cause } 2 \\
\end{array}$ & Cause 3 \\
\hline \multirow[b]{3}{*}{ Market (M4) } & Dues Payment & \multirow{2}{*}{\multicolumn{2}{|c|}{ Low income (M3.1.2) }} \\
\hline & Reluctance (M3.2) & & \\
\hline & $\begin{array}{l}\text { Lack of cooperation } \\
\text { between BPJS and others } \\
\text { (M4.1) }\end{array}$ & $\begin{array}{l}\text { Limited human resources } \\
\text { (M4.1.1) }\end{array}$ & $\begin{array}{l}\text { Wide work area } \\
\text { (M4.1.1.1) }\end{array}$ \\
\hline \multirow[t]{2}{*}{ Information (M5) } & Lack of socialization of & Respondents' low & Respondents do not \\
\hline & BPJS (M5.1) & $\begin{array}{l}\text { understanding about BPJS } \\
\text { (M5.1.1) }\end{array}$ & $\begin{array}{l}\text { know that BPJS is } \\
\text { the right of all citizen } \\
\text { (M5.1.1.1) }\end{array}$ \\
\hline Time (M6) & $\begin{array}{l}\text { Respondents do not have } \\
\text { time to manage BPJS } \\
\text { administration }\end{array}$ & $\begin{array}{l}\text { Respondents are busy } \\
\text { working }\end{array}$ & $\begin{array}{l}\text { Respondents' high } \\
\text { living needs }\end{array}$ \\
\hline
\end{tabular}

The determination of the potential root causes of problems was based on objectives 3 and objects that often arise. Furthermore, these cases were grouped into 2, namely the causes of manageable (easily managed) and unmanageable causes (not easily managed). The controllable causes include the in-depth knowledge of BPJS, respondents who have not considered BPJS essential, painful procedures of registration, limited business capital, low income, lack of socialization, and respondents who do not have enough time to apply as BPJS participants. Unmanageable causes include the low education level of respondents and the age of respondents that generally above 40 years. Furthermore, these causes were arranged in one fishbone diagram as presented in Figure 1, to facilitate in understanding the purposes of the low participation of Employment-BPJS for informal workers.

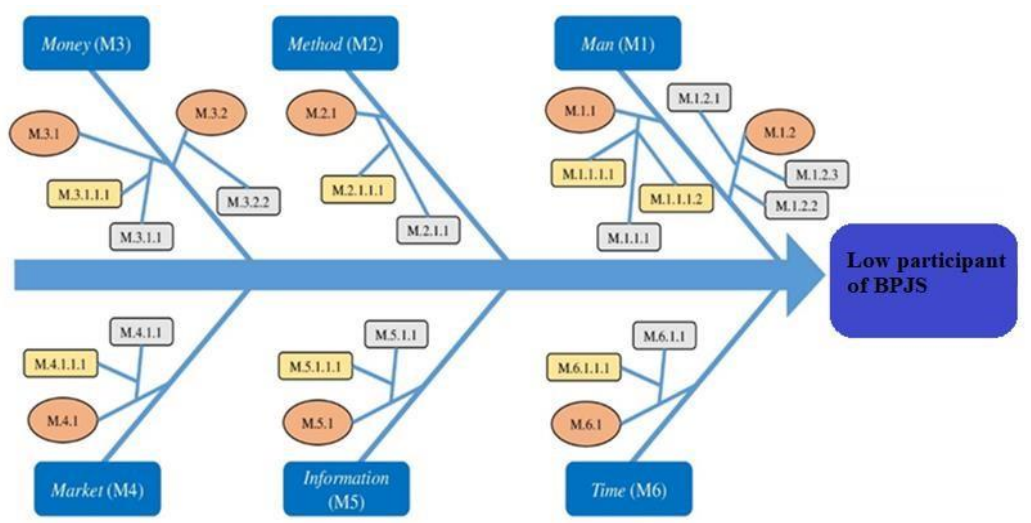

Fig.1. Diagram Fishbone of Analysis Result of The Root Problem Cause

The first potential cause of the low participation of BPJS in the informal sector is the age of respondents dominated by the age group of 40 years and above. Age is a factor that significantly influences the participation of health insurance. The results of Kansra \& Gill [4], shop owners who belong to informal workers, at a young age (30-40 years) have a higher awareness of insurance than those aged 40 years and above. Sricharoen [1], only 26.42 per cent of informal workers in Thailand are insurance participants, and they are between 21 and 30 years old. The possible culture that has evolved long ago that parents generally still rely on their children. Children are considered as assets, so independence in old age is not prepared, including in taking insurance. 
The next potential contributing factor is the low level of education. Respondents generally only have elementary to junior high school education, so that it influences the understanding of BPJS information. So, even though they have seen or heard information about BPJS, they ignore it because they feel that the data is not very important. This condition was as in Wijayanto [4] study that community participation in BPJS is low, one of which is caused by the community's low level of education. However, the low level of education is not easy to handle; it requires a lot of time and money. It can only be balanced with an increase of community knowledge about BPJS.

Low income and high living needs of respondents are also the cause of the low participation of informal workers in the BPJS. The results show that only 0.5 per cent of the friendly sector communities in Indonesia have insurance. The majority of the casual sector community does not have any insurance [3]. This possibility is due to the high price of commercial insurance premiums. Needs, such as clothing and food and entertainment, are considered far more important to fulfil. Many feels more confident and safer to invest by saving or buying property than paying for insurance policies, as the findings in this study that in the face of work risks respondents prefer keeping and surrender.

The policy of collecting premiums through the Non-PBI Mandiri scheme has also experienced difficulties with the increasing number of premium arrears on the system intended for the informal sector community. Health-BPJS data in 2015 shows a significant increase in premium arrears in many regions in Indonesia ranging from 20-50 per cent at the end of October 2015. It is, therefore, recommended that the assessment of BPJS financing potentials, mainly through revenue collection identification and premium collection methods that fit the informal sector community must be carried out [3].

The respondents' knowledge of BPJS is low. One of the causes is the lack of socialization carried out by BPJS. Agustina [6] states that the lack of socialization carried out by the BPJS is one of the causes of community participation as self BPJS participant. The community generally does not understand the administrative problems ranging from registration to payment of dues and utilization of health service facilities. BPJS has also not been able to reach all levels of society to conduct socialization. Also, during the socialization, the quality, quantity and material of socialization are not considered well, so that the community could not understand. The media must also be considered for the dissemination of information so that the community can minimize the problems and constraints faced and increase selfparticipation.

Agustina [6] also suggest that information or socialization should be carried out in various ways because the community consists of several segments. Socialization can be carried out specifically for (1) middle and upper middle segments through electronic media, socialization to housing/residential complexes, or making and distributing information leaflets for people when they pay their vehicles tax; (2) for the middle to lower segments, it can be carried out by interaction methods the public is informed of underlying messages in simple language; or it can be carried out in RT/RW, and the village; (3) optimization of Posyandu cadres, including religious leaders (TOGA), community leaders (TOMA) and traditional leaders for active participation in the socialization of the BPJS program..

Socialization is crucial to increase public awareness about insurance so that general knowledge about insurance increases. Indonesian people may have already known about insurance, but do not feel the need to become an insurance participant. This is probably due to the perception that insurance is a "business of promise". Insurance products can only be used for a long time. The participant will not even receive benefits if they do not experience a case that can be protected by insurance services. Very few people come to the insurance office to 
declare their willingness to become policyholders. The public is willing to go to the insurance office, if there are officers or insurance agents who provide explanations then offer protection services.

Knowledge of informal workers about BPJS is more influenced by friends' experiences and recommendations. Those who have good knowledge tend to get information from the experiences and recommendations of relatives or friends. If the background and recommendations given are positive, the respondent will also provide a positive response by joining the independent Health-BPJS. However, if the experience shared is negative, the respondent only knows and does not participate in the independent health BPJS [7].

\section{Conclusion}

This study concludes that the root causes of the low level of participation of respondents in Employment- BPJS are 1) the age of respondents over 40 years, 2) the low education level, 3) the small respondents' knowledge of BPJS, 4) the respondents' low income, 5) the high respondents' life needs and 6) the lack of socialization of BPJS to respondents. Those, which are included in manageable causes are 1) the low respondent's knowledge of BPJS, 2) the low respondent's income, 3) high the respondent's life needs, and 4) the lack of socialization of BPJS to respondents, while those that cannot be managed (unmanageable) are 1 ) age above 40 years and 2) low education level. But the cause of unmanageable can still be balanced by optimizing the purposes of manageable to increase the awareness of respondents in becoming BPJS participants.

\section{Acknowledgment}

This paper is a requirement for the final examination of doctoral program in environmental science, Universitas Brawijaya Malang. Thank you to the small business players from the regional superior products and the Department of Industry and Labor Magelang District.

\section{References}

[1] T. Sricharoen, "Conjoint Analysis Of Informal Worker Preference On Health Care Insurance In The Northeastern Region Of Thailand," Int. Rev. Manag. Bus. Res., Vol. 3, No. 2, P. 1105, 2014.

[2] A. D. Intiasari, L. Trisnantoro, And J. Hendrartini, "Potret Masyarakat Sektor Informal Di Indonesia: Mengenal Determinan Probabilitas Keikutsertaan Jaminan Kesehatan Sebagai Upaya Perluasan Kepesertaan Pada Skema Non Pbi Mandiri,” J. Kebijak. Kesehat. Indones. Jkki, Vol. 4, No. 4, Pp. 126-132, 2015.

[3] S. A. Adillah, Siti Ummu, "Kebijakan Jaminan Sosial Tenaga Kerja Sektor Informal Berbasis Keadilan Sosial Untuk Meningkatkan Kesejahteraan,” Yust. J. Huk., Vol. 93, 2015.

[4] W. P. Wijayanto, "Hubungan Pengetahuan Dan Kemampuan Ekonomi Masyarakat Terhadap Aksesibilitas Bpjs," J. Aisyah J. Ilmu Kesehat., Vol. 2, No. 2, Pp. 131-140, 2017.

[5] P. Kansra And H. S. Gill, "Occupational Differences In The Awareness And Perception Of Health Insurance Of Workers Employed In Urban Informal Sector Of Punjab," J. Health Manag., Vol. 18, No. 3, Pp. 410-423, Sep. 2016.

[6] Z. Agustina, T. Laksmiarti, And D. Effendi, "Pemilihan Metode Sosialisasi Sebagai Upaya Peningkatan Kepesertaan Badan Penyelenggara Jaminan Sosial (Bpjs) Mandiri,” Media Penelit. 
Dan Pengemb. Kesehat., Vol. 28, No. 1, Pp. 33-38, 2018.

[7] And S. A. Pangestika V.F., Jati S.P., "Faktor - Faktor Yang Berhubungan Dengan Kepesertaan Sektor Informal Dalam Bpjs Kesehatan Mandiri Di Kelurahan Poncol, Kecamatan Pekalongan Timur, Kota Pekalongan,” J. Kesehat. Masy., vol. 5, no. 3, pp. 39-48, 2017. 